\title{
Analysis of a 1940 Caddo Sherd Assemblage from the Millsey Williamson Site (41RK3), Rusk County, Texas
}

Timothy K. Perttula

Heritage Research Center, Stephen F. Austin State University

Follow this and additional works at: https://scholarworks.sfasu.edu/ita

Part of the American Material Culture Commons, Archaeological Anthropology Commons, Environmental Studies Commons, Other American Studies Commons, Other Arts and Humanities Commons, Other History of Art, Architecture, and Archaeology Commons, and the United States History Commons

Tell us how this article helped you.

This Article is brought to you for free and open access by the Center for Regional Heritage Research at SFA ScholarWorks. It has been accepted for inclusion in Index of Texas Archaeology: Open Access Gray Literature from the Lone Star State by an authorized editor of SFA ScholarWorks. For more information, please contact cdsscholarworks@sfasu.edu. 


\section{Analysis of a 1940 Caddo Sherd Assemblage from the Millsey Williamson Site (41RK3), Rusk County, Texas}

\section{Creative Commons License}

\section{(c) (1) \&}

This work is licensed under a Creative Commons Attribution-NonCommercial 4.0 International License 


\title{
Analysis of a 1940 Caddo Sherd Assemblage from the Millsey Williamson Site (41RK3), Rusk County, Texas
}

\author{
Timothy K. Perttula
}

\section{Introduction}

The Millsey Williamson site (41RK3) is an $18^{\text {th }}$ century Nadaco Caddo settlement and cemetery situated on an alluvial terrace on the east side of Martin Creek (Jones 1968) in the Sabine River basin (Figure 1). Some portions of the site are now covered by the waters of Martin Creek Lake, constructed in the 1970s. The site was first investigated in the 1930s, when at least 11 historic Caddo burials were excavated in the cemetery at the western end of the landform (see Jones 1968:Figure 5). In 1940, Jack Hughes, then an East Texas resident, but later a prominent Texas archaeologist, gathered a small collection of sherds from the Millsey Williamson site, and the analysis of these sherds is the subject of this article.

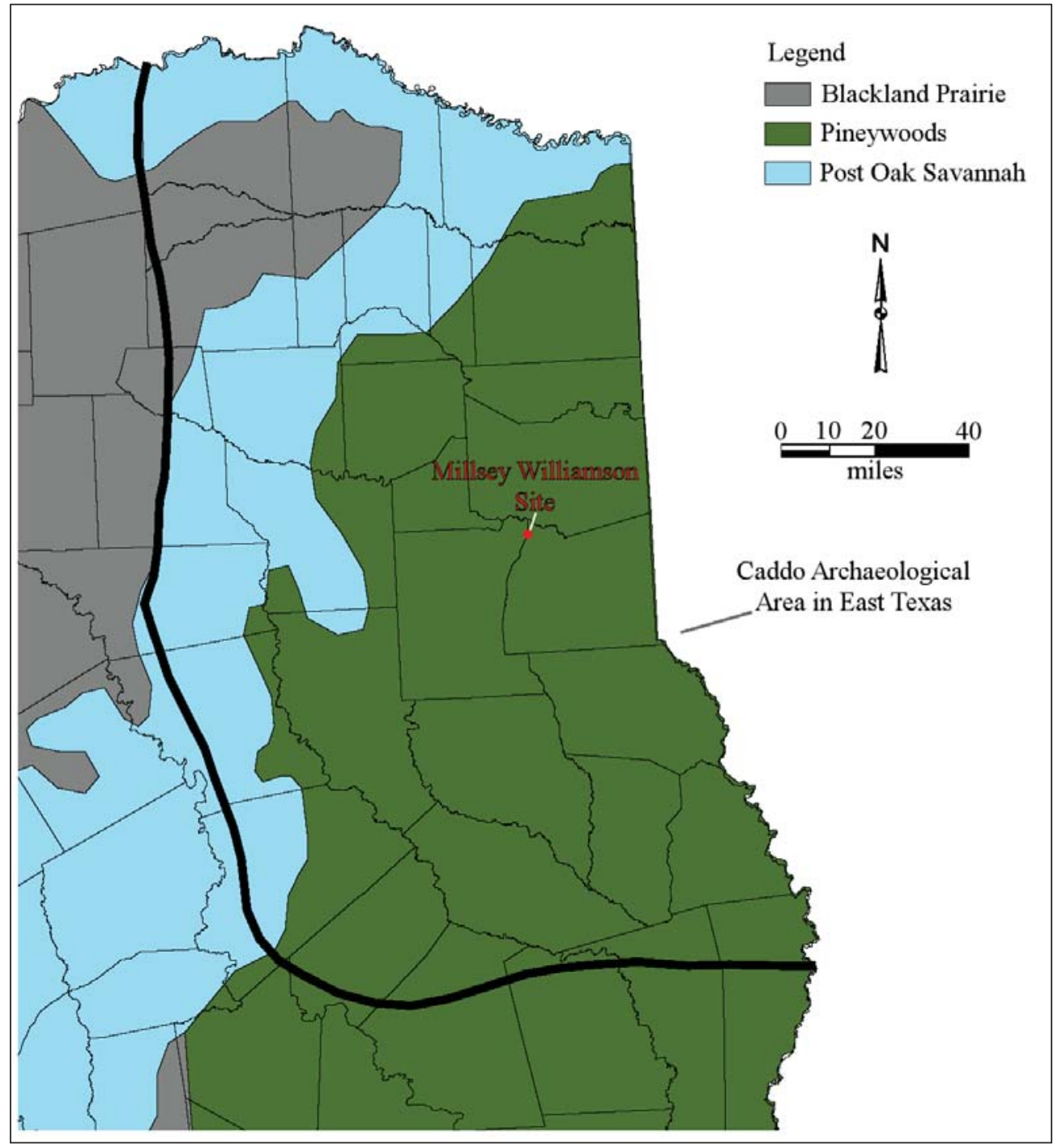

Figure 1. The location of the Millsey Williamson site (41RK3) in East Texas. 


\section{Ceramic Sherd Assemblage Collected in 1940 from the Millsey Williamson Site by Jack Hughes}

The sherd collection from the Millsey Williamson site includes sherds from plain ware, utility ware, and fine ware vessels (Table 1). About 63 percent of the sherds are from bone-tempered vessels, and the remainder are from grog-tempered vessels. Analysis of another collection of sherds from the site indicated that more than 64 percent of the sherds are from bone-tempered vessels (Perttula 2016:Table 1).

Table 1. Ceramic sherd assemblage from the 1940 surface collection at the Millsey Williamson site.

\begin{tabular}{lclll}
\hline Ware & Grog-tempered & Bone-tempered & $\begin{array}{l}\text { Grog- } \\
\text { bone- } \\
\text { tempered }\end{array}$ & N \\
\hline Plain & 15 & 14 & - & 29 \\
Utility & 6 & 20 & 1 & 27 \\
Fine & - & 1 & - & 1 \\
\hline Totals & 21 & 35 & 1 & 57 \\
\hline
\end{tabular}

Approximately 51 percent of the sherds are plain, including one plain rim, and another 47 percent are from utility wares (one tool punctated rim sherd and 26 decorated body sherds). The single fine ware sherd is from a bone-tempered vessel, and has parallel and curvilinear engraved elements. The plain to decorated sherd ratio in this small assemblage is 1.04 .

The utility ware sherds in this collection from the Millsey Williamson site are primarily decorated with brushed elements (53.6 percent of the decorated sherds) or are from vessels with secondary incised or punctated elements (Table 2). The sherds with brushed-incised and brushed-punctated decorative elements comprise another 25 percent of the utility ware sherd assemblage. These different decorated sherds are likely from Bullard Brushed jars.

Table 2. Decorative methods and elements in the utility ware and fine ware sherds in the 1940 collection from the Millsey Williamson site.

Decorative method/ $\quad$ Rim $\quad$ Body N

Decorative element

Brushed

opposed brushing marks

overlapping brushing marks

parallel brushing marks

$\begin{array}{lll}- & 1 & 1 \\ - & 1 & 1 \\ - & 13 & 13\end{array}$

\section{Brushed-Incised}

parallel brushed-incised marks and lines

parallel brushing marks and overlying

incised lines

\section{Brushed-Punctated}

opposed brushing marks and fingernail punctated row through the brushing vertical brushing marks adjacent to a tool punctated row 
Table 2. Decorative methods and elements in the utility ware and fine ware sherds in the 1940 collection from the Millsey Williamson site, cont.

\begin{tabular}{llll}
\hline $\begin{array}{l}\text { Decorative method/ } \\
\text { Decorative element }\end{array}$ & Rim & Body & $\mathrm{N}$ \\
\hline $\begin{array}{l}\text { Incised } \\
\text { parallel incised lines } \\
\text { straight incised line }\end{array}$ & - & 2 & 2 \\
$\begin{array}{l}\text { Punctated } \\
\text { horizontal tool punctated row } \\
\text { tool punctated row }\end{array}$ & 1 & - & 1 \\
$\begin{array}{l}\text { Engraved } \\
\text { parallel-curvilinear engraved lines }\end{array}$ & - & 1 & 1 \\
\hline Totals & & & 1 \\
\hline
\end{tabular}

\section{Summary and Conclusions}

The high frequency of brushed sherds in this decorated sherd assemblage at the Millsey Williamson site, as well as the common use of bone temper in vessel manufacture (e.g., Dockall and Fields 2011), suggest that this ceramic sherd assemblage, and other assemblages from the site (Perttula 2016), at the Millsey Williamson site dates well after ca. A.D. 1450. Dockall and Fields (2011) have noted that the use of bone temper increased through time in middle Sabine River archaeological sites, as sherds with bone temper in earlier Middle Caddo period (ca. A.D. 1200-1400) components at 41HS231, 41HS574, 41HS844, and 41HS846 account for only 10-37 percent of the vessel sherd assemblages, but this proportion increases to more than 50 percent at post-15 $5^{\text {th }}$ century sites/components at Pine Tree Mound (41HS15) (Fields and Gadus 2012), 41HS573, 41HS843, and 41RK557; bone-tempered sherds comprise more than 63 percent in this Millsey Williamson sherd assemblage. These post-A.D. 1450 ceramic assemblages are dominated by brushed wares, comprising more than 50 percent of the decorated sherd assemblages.

There are no sherds in this sherd assemblage at the Millsey Williamson site that can be identified as belonging to a post-A.D. 1680 Caddo ceramic assemblage (i.e., Simms Engraved, Keno Trailed, or Natchitoches Engraved). Nevertheless, given the vessels documented in burial features at the site (Jones 1968; Perttula and Nelson 2014), and the very high proportion of brushed sherds in this assemblage, it is likely the case that the small ceramic assemblage from the Millsey Williamson site discussed in this article represents an occupation by $17^{\text {th }}$ century Caddo peoples probably affiliated with a Nadaco Caddo community.

\section{Acknowledgments}

I thank Marybeth Tomka of the Texas Archeological Research Laboratory at The University of Texas at Austin for her help in accessing the Hughes collection from the Millsey Williamson site. Sandy Hannum prepared Figure 1 in this article. 


\section{References Cited}

Dockall, J. E. and R. C. Fields

2011 National Register Testing of Three Sites in the Sabine Mine's South Hallsville No. 1 Mine-Rusk Permit, Rusk County, Texas. Report of Investigations No. 162. Prewitt and Associates, Inc., Austin

Fields, R. C. and E. F. Gadus (editors)

2012 Archeology of the Nadaco Caddo: The View from the Pine Tree Mound Site (41HS15), Harrison County, Texas. 2 Vols. Reports of Investigations No. 164. Prewitt and Associates, Inc., Austin.

Jones, B. C.

1968 The Kinsloe Focus: A Study of Seven Historic Caddoan Sites in Northeast Texas. Master's thesis, Department of Anthropology, University of Oklahoma, Norman.

Perttula, T. K.

2016 Ceramic Sherds from the Millsey Williamson Site (41RK3), Rusk County, Texas. Journal of Northeast Texas Archaeology 61:17-20.

Perttula, T. K. and B. Nelson

2014 The Millsey Williamson (41RK3), Bead Burial, and L. N. Morwell Farm Sites on Martin Creek: Historic Caddo Settlements along Trammels Trace, Rusk County, Texas. Journal of Northeast Texas Archaeology 44:23-46. 